\title{
Spanish South American and Brazilian Demonyms: Morphosyntactic Structure and Axiological Values
}

\author{
Olga S. Chesnokova $\bowtie$, Marija Radović, Irina B. Kotenyatkina \\ Peoples' Friendship University of Russia (RUDN university), \\ 6, Miklukho-Maklaya str., Moscow, Russian Federation, 117198 \\ \tchesnokova-os@rudn.ru
}

\begin{abstract}
This article contributes to the study of the grammar, semantics, expressive values of a very special onymic category, inhabitants' names, or demonyms. The authors examine and compare demonyms in two varieties of Romanic languages - South American Spanish and Brazilian Portuguese from both a multi-modal point of view and empirical evidence (synchronic and diachronic data) and systemize them by concentrating on their morphosyntactic distinctive features and semiotic content. The perspective revealed in this paper aims to study, define and analyze the main tendencies in the creation of denominative adjectives functioning as demonyms, to establish the parameters of discrepancies and convergences regarding demonyms of the region in question. The authors based on analyzing the motivation sources, grammar formulae, suffix combinations, socio-cultural varieties and the occurrence of homonymy, as well as their significance, axiological values in forming a group identity and the stereotypes they might lead to. The methodology has included semiotic, cognitive, historic and comparative analysis - a synchronic conceptual transdisciplinary analysis. The results of the study confirm the premise that the demonym suffixes randomly alternate in derivation processes, but also demonstrate the existence of other morphological and pragmatic trends while outlining the role of demonyms in migration processes, formation of a linguistic landscape and axiological values.
\end{abstract}

Key words: demonyms, morphosyntax, axiological values, South America, Spanish, Brazilian Portuguese

\section{Article history:}

Received: 01.03.2021

Accepted: 15.04 .2021

\section{For citation:}

Chesnokova, O.S., Radović, Marija \& Kotenyatkina, I.B. (2021). Spanish South American and Brazilian Demonyms: Morphosyntactic Structure and Axiological Values. RUDN Journal of Language Studies, Semiotics and Semantics, 12(3), 576-596. doi: 10.22363/2313-2299-2021-123-576-596

(C) Chesnokova O.S., Radović Marija, Kotenyatkina I.B., 2021

This work is licensed under a Creative Commons Attribution 4.0 International License https://creativecommons.org/licenses/by/4.0/ 


\title{
Испанские южноамериканские и бразильские демонимы: морфосинтаксическая структура и аксиологические ценности
}

\author{
О.С. Чеснокова $\bowtie$, М. Радович, И.Б. Котеняткина \\ Российский университет дружбы народов, \\ 117198, Российская Федераџия, Москва, ул. Миклухо-Маклая, д. 6 \\ $\bowtie$ tchesnokova-os@rudn.ru
}

\begin{abstract}
Аннотация. Статья посвящена исследованию грамматики, семантики, выразительных средств особой онимической категории - имен жителей или демонимов. Авторы исследуют и сравнивают демонимы в двух романских языках: южноамериканском испанском и бразильском португальском с разных точек зрения, опираясь на эмпирические (синхронные и диахронические) данные и систематизируют их, концентрируясь на тх морфосинтаксических отличительных особенностях и семиотическом содержании. Перспективу дальнейших исследований авторы видят в изучении, определении и анализе основных тенденций в создании отыменных прилагательных, функционирующих как демонимы, для установления параметров несоответствий и совпадений в отношении демонимов рассматриваемого региона. Анализ проведенного исследования в формировании групповой идентичности и стереотипов, к которым они могут привести, опирается на анализ источников мотивации, грамматических правил, суффиксных комбинаций, социокультурных разновидностей и наличия омонимии, а также аксиологической значимости демонимов. Методология включает семиотический, когнитивный, исторический и сравнительный, а также синхронный концептуальный междисциплинарный анализ. Результаты исследования подтверждают предположение, что суффиксы демонимов случайным образом чередуются в процессах образования, но также демонстрируют существование других морфологических и прагматических тенденций, подчеркивая роль демонимов в процессах миграции, формировании языкового ландшафта и аксиологических ценностей.
\end{abstract}

Ключевые слова: демонимы, морфосинтаксис, аксиологические ценности, Южная Америка, испанский, бразильский португальский

\section{История статьи:}

Дата поступления: 01.03.2021

Дата приема в печать: 15.04.2021

\section{Для цитирования:}

Чеснокова О.С., Радович М., Котеняткина И.Б. Испанские южноамериканские и бразильские демонимы: морфосинтаксическая структура и аксиологические ценности // Вестник Российского университета дружбы народов. Серия: Теория языка. Семиотика. Семантика. 2021. Т. 12. № 3. С. 576-596. doi: 10.22363/2313-2299-2021-12-3-576-596

\section{Introduction}

Demonyms are directly related to toponymy and represent an integral part of the lexicon and toponymic vocabulary of every language. However, the formation of this lexicon as well as its current condition and frequency in texts and discourses depend on the typology of a particular language, its history, linguistic contacts and 
national rhetoric tradition. This investigation aims at studying South American demonyms from Argentina, Chile, Paraguay, Uruguay, Peru, Ecuador, Bolivia, Colombia, Venezuela and Brazil basing on the cartographic materials, dictionaries, diverse types of texts, and surveys of native speakers. The fact that serves as a theoretical premise is that in contemporary Romance philology Spanish and Portuguese are perceived as a set of parameters of differences and convergences $[1-4]^{1}$. In other words, toponyms can be studied as markers of the way speakers of different varieties of Spanish and Portuguese perceive the world, which combines the goals of traditional onomastic geography and studies in dialectology and semiotics and draws particular attention to national toponymic systems and their consecutive comparison.

The essence of this study consists in revealing the linguistic versatility in South American countries through its evidence in the field of toponymy as well as the formation of demonyms, productivity of suffixes and formation of metaphorical demonyms or toponymic nicknames.

\section{DEMONYMS AS A PART OF TOPONYMIC LEXICON AND THEIR DISCURSIVE POTENTIAL}

\section{Definition and formation of demonyms}

Before we turn to discussing in detail the practical results of our study, there is a need to outline the slight dissents that exist about the demonym as a term.

The Spanish Royal Academy defines demonym as follows:

From lat. gentilicius, der. de gentīlis 'which belongs to one nation or lineage'.

1. adj. About an adjective or a noun: the one denoting the relation to a geographical area.

2. adj. Pertinent or related to peoples or nations.

3. adj. Pertinent or related to a lineage or a family.

The term demonym is the English equivalent for the Spanish word gentilicio and applies to an inhabitant or a native of a particular place, and is derived from a toponym. However, the word gentilic is defined by Webster's dictionary of English in a narrower sense, as a noun or an adjective that denotes an ethnic or a national affiliation. In Spanish this term applies not only to inhabitants of certain places but is also used as a denominative adjective, i.e., the one derived from a geographic denomination.

According to Morera and García Padrón, gentilic words have a primary ("pertinent or related to", "native of") and, sometimes, a secondary meaning (descriptive, classified as a noun - las menorquinas, el afgano, la malagueña). In addition, these authors distinguish various traits attributed to people called by their

\footnotetext{
${ }^{1}$ Buarque de Holanda Ferreira, A. (1986). Novo dicionário da língua portuguesa. Rio de Janeiro: Nova Fronteira. (In Portuguese).
} 
demonyms: 1) moral qualities (bárbaro,fenicio); 2) physical or psychological traits (flaca como una francesa; paciente como un chino); 3) attitudes or behaviors (furia española, flema británica); 4) amount of property (rico como un godo); 5) sexual practices (sodomita, lesbiana); 6) ideological or religious position (política francesa, diplomacia vaticana); 7) economic or professional activities (banquero suizo, asistenta filipina); 8) language or linguistic variety (gabacho); 9) attire, clothes, jewelry (saboyana); 10) object, tool, currency (boliviano, carabela portuguesa); 11) food or drink (paella valenciana, boloñesa, macedonia); 12) music or dance (granadina, malagueña); 13) games and sporting activities (fútbol americano, baraja española); 14) objects of art or craft (punto tunecino, tela indiana); 15) established school or institute (cirenaico) [5. P. 463-65].

On the other hand, Almela Perez distinguishes the apophantic and the semantic aspect of demonyms and adds that the semantic aspect implies the possibility of the triple meaning, including the identifier, the subclassifier, and the analogue [6. P. 16].

It is well known that in the course of history the evolution of the lexicon and grammar of Spanish were immensely affected by Latin, which is seen from the examples of the most typical Spanish suffixes for demonyms, i.e., -ano, -ana (Latin: -anus/-ana/-anum); -ense (Latin: -ensis); -ino, -ina (Latin: -inus/-ina/inum); -eño, -eña (Latin: -ineus/-inea/-ineum) [7].

It must be said that the founder of contemporary Romance philology in Russia G.V. Stepanov asserted in the 1970s that in the process of toponymic derivation suffixes for demonyms in Spanish are chosen not according to specific rules, but are influenced by the existing linguistic tradition, i.e., an inconsistent alteration of the most productive suffixes occurs [3. P. 256]. This hypothesis has been also stated by Chilean authors Kordic and Fajardo, who claim that it is impossible to guess the suffix that will form the demonym for each place name [8. P. 418].

\section{Demonyms as indicators of social and cultural practices}

Demonyms reflect complex relations among culture codes, multilingual and social creativity and can be considered as a clear example of Translanguaging, the transforming and transdisciplinary mind process that goes much more beyond (transcends) language [9]. The field of demonyms is closely connected to the way we are recognized as a society and to the existing social stereotypes and models of treating regional groups. Demonyms represent a flexible and constantly evolving system. For example, after the collapse of the Soviet Union, a new demonym poccuяне [rossiyánie] emerged as referring to the residents of the Russian Federation. In certain regions of ex-Yugoslavia new words were invented to denote their residents belonging to different ethnicities such as Bosniaks/Bosniacs. ${ }^{2}$ On the other hand, the demonym Yugoslav is now being used to refer to the mentioned period of history and can be used in a nostalgic sense by the peoples populating this area.

\footnotetext{
2 Bosniaks/Bosniacs is the demonym used to denote Muslim population of Bosnia and Herzegovina.
} 
Demonyms typically present a flexible category. Due to global migration process, the place of birth does not always coincide with the place of residence or space of popularity of a person [10]. For instance, according to her citizenship, a popular Latin American writer, Isabel Allende, is Chilean, but Peruvian (peruana) by her birthplace. Diverse types of texts and discourses in Spanish and Portuguese abound with demonyms in these languages. In general, Spanish and Portuguese demonyms are difficult to translate into, for example, Slavonic languages. Slavonic languages morphosyntactic recourses permit Spanish and Portuguese demonyms formation, but they sound rather artificial for Slavonic languages native speakers. Which is why in many cases Slavonic languages native speakers prefer descriptive constructions, but not demonyms: житель Боготьл 'inhabitant of Bogota' instead of боготинеи for bogotano 'Bogotan'; житель Сантьяго or stanovnik Santjaga 'inhabitant of Santiago' instead of сантьягеu for santiaguino.

A special approach to demonyms consists in studying them in a dialogue of cultures, which is a form of Translanguaging as well. These considerations go back to the ideas of dialogue suggested by the great Russian thinker M.M. Bakhtin in his work "The Aesthetics of Verbal Creativity", that in the multicultural interactions one of the cultures puts questions to another one, and due to such issues, one culture opens its depths to another one; in our case, this corresponds to the low frequency of similar demonyms in Slavonic tongues [11].

The following example from media discourse perfectly underscores the multiplicity of culturally marked examples of demonyms:

'Nace la cátedra García Márquez en la Universidad Central'

En honor a la memoria de nuestro Nobel de Literatura, la Universidad Central de Bogotá inaugura este martes - cuando el autor cataquero cumpliría 91 años-, la cátedra Gabriel García Márquez, que cada año, durante un día, rendirá tributo a su pensamiento $(1)^{3}$.

'The Central University opens a new Department named by García Márquez'

In honour of the memory of our Nobel Prize Winner in Literature, the Bogota's Central University inaugurates on Tuesday - exactly when the cataquero author would turn 91 - the Gabriel García Márquez Department that will for a day give tribute to his thinking each year.

To decipher and interpret the demonym cataquero applied to the Colombian Nobel Prize, one needs to know that Cataca is the short form of the toponym Aracataca, Marquez' native city: "Its name goes back not to the people but to the river named ara in the Chimila language and to Cataca, which is the word the community used to identify the indigenous governor. Which is why the natives call the city not Aracataca but as it should be called, i.e., Cataca". ${ }^{4}$ That's the way to decipher the

\footnotetext{
${ }^{3}$ Nace la cátedra García Márquez en la Universidad Central. El Tiempo, 4 de marzo de 2018. URL: https://www.eltiempo.com/cultura/musica-y-libros/universidad-central-inaugura-catedra-garciamarquez-189704 (accessed: 19.09.2020). (In Spanish).

${ }^{4}$ García Márquez, G. (2002). Vivir para contarla. Bogotá: Editorial Norma. P. 53.
} 
expression cataquero writer referred to the Colombian Nobel Prize winner in the context of his autobiography and in other Colombian culturally bound texts.

\section{SOUTH AMERICAN TOPONYMY AS A SOURCE IN THE FORMATION OF DEMONYMS}

Needless to say that the nation and language are the basic characteristics of ethnic and cultural identity. Every nation in Latin America is a complex alloy of distinct ethnic elements. The significance of toponymy of the countries of Latin America is difficult to disregard given that it often reveals the influence of substrate idioms on the etymology of geographic names and brings to light the already disappeared characteristics of place names [12-14]. In semiotic studies of place names the emphasis is put on analysing their position among the diverse systems of signs and on interpreting place names along semantic, syntactic, and pragmatic lines as the three basic dimensions of signs. In terms of semiotics, place names reflect and catalog the space. According to Yu.M. Lotman, the semiotics of space is of key importance to the formation of "the image of the world" for a specific culture. The interpretation of life through culture is inevitably based on the formation of the model of the universe and space [15. P. 205].

Place names can actually be viewed as the all-encompassing linguistic mapping of the model of the universe. Since Spanish is treated in contemporary Romance philology as a set of parameters of differences and convergences, as well as Brazilian Portuguese, place names can be studied as markers of the way speakers of diverse varieties of Spanish and Portuguese perceive the universe, while combining traditional onomastic geography and studies in dialectology and semiotics. Another relevant line of enquiry to be pursued is the role of demonyms in language and cultural contacts, as well as their borrowings from and assimilation by other cultures.

It is well known that the system of Latin American place names has been formed under the influence of objective factors of the geographic and linguistic landscape, sociocultural development of the nations of Latin America and intercultural contacts, the factor in which the heritage of pre-Colombian cultures and indigenous languages stands out. Numerous Latin American toponyms reproduce European toponyms, which serves as yet another proof of the continuing and transforming interweaving of the peninsular and the indigenous cultures. Another part of the intercultural dialogue are the sources of Spanish both in the field of common nouns and in the domain of proper nouns as cultural markers in the toponymic field.

Latin American geographic names are obviously related to the different stages of history of the Spanish-speaking countries. They outline the diversity of motives in the processes of nomination and the associative references, as well as the range of grammar features and aesthetic resources, all of which allow reconstructing models of space perception diachronically and, consequently, reconstructing the dialogue between the past and the present of toponymy. 
Just like with the toponymy of Latin America in general, which has been asserted several times, we propose to classify South American place names into various groups: those originating from indigenous languages and carrying explicit indigenous components; the ones from the times of the European conquest of the American continent as a whole, with the dominance of sources of Spanish; place names covering the period from declarations of independence by Latin American countries to the present day, in which case one of the dominant tendencies is to borrow resources of proper names $[16 ; 17]$. In each of these three clusters, there are place names that originate from proper (first of all, personal, i.e., anthroponymic place names) and common nouns by creating diverse meaning-making combinations. This approach must be expanded by adding names of African origin [18. P. 24-26].

\section{BASIC MORPHOLOGICAL FORMATIVE RESOURCES FOR SOUTH AMERICAN DEMONYMS}

Our quantitative productivity analysis of suffixes of South American demonyms consists in extracting examples of demonyms derived from the major place names of every Spanish-speaking country on the continent and of Brazil; it should be taken into account that the procedure involves two languages with a high share of coincident morphological resources. We selected the most frequently used demonyms of every country, i.e., derived from macrotoponyms and toponyms serving to name the most populous cities. The analysed content covers 995 examples, including 153 from Argentina, 155 from Chile, 43 from Paraguay, 61 from Uruguay, 44 from Bolivia, 94 from Peru, 63 from Ecuador, 104 from Venezuela, 278 from Brazil. For the detailed information about the demonyms of Colombia see the work by Colombian lexicographers "Dictionary of Demonyms of Colombia" published in 2008, whereas the results of our analysis of the sampled Chilean demonyms are confirmed by the data from the work by Chilean linguists Raïssa Kordić Riquelme and Mario Ferreccio "Demonyms and Toponyms of Chile" published in 2014 [19].

\section{Argentina}

In Argentina the most widespread suffix for demonyms is -ense appearing 25 times in our sample of demonyms (bahienense, bahiense, barilochense, belgranense, bonaerense, comodorense, concordiense, chubitense, chubutense, gualeguayense, gualeguaychense, gualeguaychuense, juninense, platense, marplatense, moronense, paranaense, rawsense, riocuartense, riogalleguense, rioplatense, isidrense, tandilense, ushuaiense, viedmense). Next comes the suffix eño found in 15 examples (porteño, azuleño, catamarqueño, chaqueño, formoseño, neuqueño, posadeño, chaqueño, salteño, sanluiseño, nicoleño, jujeño, santacruceño, santarroseño, santiagueño), followed by -ino found in ten cases (correntino, mendocino, neuquino, rionegrino, rosarino, sanjuanino, sanrafaelino, 
santafecino, santafesino, fueguino). Next come -ano, -és, -ero, -o, -ico plus the zero suffix in case of patagón.

\section{Chile}

It should be mentioned that in Chile the most used suffix for demonyms is ino, found 22 times in the toponyms of the country's major cities (santiaguino, antofagastino, coihaiquino/coyhaiquino, copiapino, curanipino, chañaralino, frutillarino, iloquino, lonquimayino, elenino, osornino, padrehurtadino, padrelascasino, puconino, puertomontino, natalino, portovarino, rancagüino, aconcagüino, talquino, viñamarino, yerbabuenino), which represent some $40 \%$ of the lexicon sampled for our statistical research. The next most frequent suffix is -ense (11 ex.): curanipense, chiloense, chillanense, iloquense, pascuense, lebunense, serenense, panguipullense, puntarenense, temuquense, villarricense. Nevertheless, not only is this suffix considered dominant in the neighbouring Argentina, but also in Brazil. On the other hand, -eño is found in seven examples being ariqueño, atacameño, castreño, chilhueño, iquiqueño, sanfelipeño, porteño. A similar frequency of usage is observed in case of -ano (5 ex.) in such demonyms as ancuditano, coquimbano, tocopillano, valdiviano, villaricano. Such suffixes as -ista, -ón, -ote, -ejo, -ico, and -eno are each found in one case only. The zero suffix is found in place names consisting of more than one word and the respective demonyms in those cases retain the initial capitals: María Pinto and Última Esperanza. This phenomenon seems understandable due to the lexical complexity of these place names; nor would it be strange if the demonyms included only one and salvanot both components - in that case we would suggest such variants as pinteño, esperancino [20. P. 24-26].

\section{Paraguay}

Unlike in Argentina and Chile, the most productive suffix in the demonyms of Paraguay is -eño (chaqueño, caaguaceño, caazapeño, centraleño, guaireño, chaqueño, esteño, luqueño, capiateño, lambareño, limpeño, roquealonseño, franqueño, itagueño, villariqueño-guaireño, caacupeño, iteño); it is used in almost half of our analysed examples and followed by -ense (altoparanaense, paranaense, amambayense, canindeyuense, hernandariense, itapuense, ñembyense, ovetense, paraguariense, paraguariense, pilarense) and smaller numbers of various others (-ano, -ero, -eno, -ino).

Unlike the demonyms of Uruguay that are also part of our sample, the examples from Paraguay show the tendency of keeping the lexeme San:

San Pedro (department) - sampedrano (alveolar -n- changes to labial -m-);

San Antonio - sanantoniano;

San Lorenzo - sanlorenzano.

In the rest of the cases, when the place name contains more than one element, one of them is omitted while deriving the corresponding demonym: 
Departamento Central - centraleño;

Ciudad del Este - esteño;

Fernando de la Mora - fernandino;

Coronel Oviedo - ovetense;

Pedro Juan Caballero - pedrojuanino;

Presidente Franco - franqueño;

Mariano Roque Alonso - roquealonseño.

Considering the fact that homonymy is not infrequent in the place name motivation, we have come across a series of examples of homonymy in the cluster of demonyms related to Rio de la Plata:

Misiones (Paraguay) / Misiones (Argentina) - misionero;

Fernando de la Mora (Paraguay) / Maldonado (Uruguay) - fernandino.

However, it should be stressed that this is only a tendency that must not be treated as a general rule, having in mind that the toponyms Asunción (Paraguay) y La Asunción (the capital of the Nueva Esparta department in Venezuela) serve to show us an opposite case, since the related demonyms (asunceno and asuntino) were made up using different suffixes: (-eno and -ino).

\section{Uruguay}

We have come to conclusion that the suffixes of the Uruguayan demonyms are similar in terms of productivity to the case of Argentina: -ense (artiguense, artiguense, barrosblanquense, cerrolarguense, costense, coloniense, coloniense, duraznense, duraznense, floridense, floridense, pedrense, maldonadense, maldonadense, melense, pandense, rionegrense, riverense, riverense, rochense, rochense, sorianense, tacuaremboense, tacuaremboense, rioplatense) is the most popular one, whereas the next positions belong to -ino, -ano, -ario, -ero, and -eño, which is found in Uruguay only thrice.

However, having studied the demonyms of Uruguay, we detected eight examples of double demonyms, i.e., two variants used to refer to the inhabitants of the same place. These demonyms can be grouped into: 1) synonymic demonyms (or cases of a second demonym): uruguayo - oriental, maldonadense fernandino, treintaitresino - olimareño and 2) official demonym - toponymic nickname: cerrolarguense- arachán, floresino - poronguero, melense — arachán, josefino - maragato, trinitario - poronguero. It is necessary to highlight here the first synonymic triplet we encountered: lavallejino, serrano, minuano.

In terms of word derivation the morphology of Uruguayan demonyms is quite peculiar. There are several demonyms standing out such as josefino (of the San Jose department and its capital San José de Mayo) and sanducero (of the Paysandú department and its homonymous capital), where the introduction of a consonant affix (-f- and -c-) shows the tendency to retain the final accentuated syllable. ${ }^{5}$

\footnotetext{
${ }^{5}$ In the demonym sanducero the toponym's first syllable pay is omitted. This phenomenon is also observed in the toponymic material from Columbia, e.g., samario (Santa Marta), bumangués (Bucaramanga).
} 
The expected forms or, to put it better, foreseeable ones, would be (san)joseño/josino, sandino/sandeño. In addition, we should emphasize the example of tacuaremboense (for the city and department of Tacuarembo), already without an affix. A similar morphological method of deriving demonyms from oxytone place names is observed in Brazil, country with state borders with Uruguay:

Carandaí - carandaiense;

Feijó - feijoense;

Macapá - macapaense;

Maceió - maceioense;

Tauá - tauaense.

\section{Bolivia}

The fact that the situation in Bolivia is more distinct than in the neighbouring countries is confirmed by the occurrence frequency of the suffix -eño found in 32 examples (aiquileño, alteño, apoleño, araneño, arqueño, ayopayeño, camireño, capinoteño, cliceño, cobijeño, cruceño, chapareño, chaqueño, chuqisaqueño, llallagueño, mizqueño, orureño, paceño, punateño, puneño, quillacolleño, riberalteño, sacabeño, tapacareño, tarateño, tarijeño, tiraqueño, totoreño, tupiceño, viacheño, villamonteño, yacuibeño); as a comparison, -ino and -ense are found in five and four examples, respectively. It goes without saying that in Bolivia the intrinsic complexity of contacts between Spanish and the indigenous languages is very noticeable. A case of interest is the demonym movima used to refer to the inhabitants of the city Santa Ana del Yacuma, stemming from the name of the indigenous language and the people speaking it in this region.

\section{Peru}

Getting down to the material of Peru, we have to mention that the official demonyms of the departments and their homonyms for capitals (Arequipa, Ayacucho, Cajamarca, Cuzco, Huancavelica, Huánuco, Ica, Moquegua, Piura, Puno, Tacna, Tumbes, Callao) coincide in all the cases. However, the city of Ayacucho has an alternative demonym, huamanguino, which stems from the province where the city is located.

In terms of productivity the leading suffix is -eño found in 33 examples from our sample: apurimeño, arequipeño, cuzqueño, huanuqueño, iqueño, liberteño, limeño, pasqueño, puneño, tacneño, arequipeño, cuzqueño, cusqueño, huanuqueño, iqueño, iquiteño, cerreño, puneño, tacneño, pucallpeño, juliaqueño, limeño, paiteño, bellavisteño, camaneño, chongoyapeño, colliqueño, comeño, ilaveño, ileño, jimbeño, santeño, villasalvadoreño.

Next come such endings as -ino and -ano, whereas the suffix -ense, so widespread in the neighbouring countries, is found in six examples only.

There are various examples of homonymic demonyms, i.e., twin demonyms, one of which is official and the other is alternative: 
Limeño - limense (Lima, department);

Tacneño - tacnense (Tacna, department and city);

Ayacuchano - huamanguino (Ayacucho, city);

Pucallpino - pucallpeño (Pucallpa, city);

Chimbotano - chimbotero (Chimbote, city); ${ }^{6}$

Camanejo - camaneño (Camaná, city).

\section{Ecuador}

The situation with the demonyms of Ecuador and the productivity of their suffixes does not differ much from the aforementioned cases. The undoubtedly most frequent endings are -ense y -eño found in 27 and 20 examples, respectively. Oddly enough, the first one prevails in the examples of provincial demonyms (bolivarense, carchense, cotopaxense, moronense, santodominguense), whereas the latter is found more often in the forms derived from the names of the capitals of Ecuador's provinces (guarandeño, guayaquileño, ibarreño, santodomingueño, tulcaneño).

Such suffixes as -ejo (cañarejo), -ar (peninsular), -ero (chonero), -aco (guayaco), -o (azuayo), and -ita (manabita) are each found only in one example of our sample. Still, it is worth highlighting the unique example containing the suffix -beo among all the South American demonyms encountered during our quantitative analysis. We mean the word macabeo, used to refer to the residents of the city of Macas, the capital of the Morona Santiago province known among the Ecuadorians under the metaphoric periphrase of La Esmeralda Oriental.

The population of the Manabi province is referred to not only by the official demonym Manabita but also quite often by the colloquial name manaba included in the DRAE. In his book "This is Manabí" Gustavo Álvaro Silva explains:

Manabi has a distinct ethnic and cultural identity exteriorized in the manabita montubios and cholos, who are different racially but have similar national characters and customs, which allows treating manaba as one identity. [...] Being a montubio or a cholo has often been an object of disdain; the term manaba is used with contempt in other parts of the country, but the residents of this province have managed to overcome this despicable attitude with strength endowing them with inner pride ${ }^{7}$.

It is also worth underlining santodominguense and santodomingueño as the demonyms for Ecuador's Santo Domingo de Tsáchilas province and its capital Santo Domingo de los Colorados. The place names with the same religiously marked formative element are found in other Spanish-speaking countries as well:

Santo Domingo (Costa Rica) - domingueño;

\footnotetext{
${ }^{6}$ The demonyms chimbotero is also used as toponymic nickname for migrants who come to work to the city of Chimbote.

${ }^{7}$ La identidad manaba sí existe. La Hora, 19 January 2003. URL: https://ahora.com.ec/noticia/ 1000135833/identidad-manaba-sc3ad-existe (accessed: 12.09.2020). (In Spanish).
} 
Santo Domingo (capital of the Dominican Republic) - capitaleño;

Santo Domingo de la Calzada (La Rioja, España) - calceatense.

\section{Colombia}

The most widely used suffix singled out by the authors of the Dictionary of Demonyms of Colombia is - eño with $27.9 \%$ of matches, followed by -ense and ano. ${ }^{8}$ It is interesting to compare the case of Colombia with Chile, where-ense is also second, whereas the leading suffix among the demonyms from Chile is -ino, hardly ever used in Colombia and found in the seventh place with $3 \%$ of matches. The curious fact is that Colombia has only one demonym ending with - uso pastuso, used to refer to the residents of the city of Pasto and the Nariño department.

Because of its morphological and pragmatic criteria, the classification of Colombian demonyms suggested by the authors of the above mentioned Dictionary is provided below and appears applicable to the toponymic material from the other countries in the region we analysed.

1) Official demonyms: the only or the most used variant of demonyms with their roots containing place names from which the former are derived (bogotano, boyacense, cundinamarqués, pereirano);

2) Second or alternative demonyms are other official variants of demonyms derived from respective place names. Alternative demonyms do not prevail over official variants (florentino - florenciano, riorense - riodorense, trujillano trujillense);

3) Unconventional demonyms (suppletives) are also considered official, but without place names as their roots. They possess by a broad variety of motivation and do not always represent unique forms of naming inhabitants of specific places (cataquero, bumangués, opita, regiomontano);

4) Colloquial and xenophobic demonyms are colloquially used demonyms most of which have an emotional or characterizing stylistic nuance (cachaco, corroncho, veneco). ${ }^{9}$

\section{Venezuela}

According to the results of analysing the productivity of the suffixes of the demonyms from Venezuela, -eño and -ense show very similar occurrence frequency rates, though -ense is behind - eño by just two examples, with 33 cases of using the latter: apureño, aragüeño, carabobeño, cojedeño, guariqueño, merideño, portugueseño, angostureño, sancarleño, caraqueño, merideño, tequeño, guanareño, guaireño, sanfelipeño, calaboceño, acarigüeño, araureño, yaritagüeño, turmereño, guatireño, porteño, porteño, tereseño, cabudareño,

\footnotetext{
${ }^{8}$ Sociedad Geográfica de Colombia, Academia de Ciencias Geográficas (2008). Diccionario de gentilicios de Colombia, IGAC. Bogotá: Imprenta Nacional de Colombia. P. 168. (In Spanish).

${ }^{9}$ Sociedad Geográfica de Colombia, Academia de Ciencias Geográficas. (2008). Diccionario de gentilicios de Colombia, IGAC. Bogotá: Imprenta Nacional de Colombia. pp. 121-156. (In Spanish).
} 
ocumareño, cueño, zaraceño, luciteño, cagüeño, tovareño, quiboreño, caicareño. The examples ended in -ense (31 ex.) are: amazonense, anzoatiguense, bolivarense, larense, monaguense, sucrense, tachirense, varguense, bolivarense, tucupitense, tequense, sancristobalense, puntofijense, porlamarense, cabimense, citojense, tigrense, barbarense, santaricense, guayense, vigiense, machiquense, anaquense, vallepascuense, guasdualitense, cagüense, mariarense, upatense, ejidense, charallavense, limonense.

The third place is taken by -ano (18 ex.): venezolano, deltano, falconiano, neoespartano, trujillano, yaracuyano, zuliano, ayacuchano, valenciano, coriano, barquisimetano, trujillano, guayasitano, valerano, portocruzano, victoriano, villacurano, tocuyano. Next come the suffixes -ero (9) (maracayero, sanjuanero, maracaibero, tinaquillero, guarenero, orchilero, carupanero, taribero, corobero) and -és (barinés (state of Barinas), barcelonés, barinés (city of Barinas), maturinés, cumanés, guayanés). The ending -ino was found in five examples from our sample: capitalino, mirandino, sanfernandino, asuntino, marabino.

The suffix -al (oriental) is found only in one of the analysed examples, i.e., in the name used for the residents of the state of Anzoátegui in the east of Venezuela and it accentuates their "easternness". The three suppletive demonyms highlighted are angostureño (city of Bolivar), maracucho (Maracaibo), and corobero (Caicara del Orinoco); they represent alternative demonyms for the indicated cities.

It should be noted that we have found the following homonymic (twin) forms of Venezuelan demonyms paired as official-alternative and official-suppletive:

anzoatiguense-oriental (Anzoátegui, state);

bolivarense-angostureño (Ciudad Bolívar, city);

tequeño-tequense (Los Teques, city);

guayanés-guayasitano (Ciudad Guayana, city);

cagüeño-cagüense (Cagua, city);

caicareño-corobero (Caicara del Orinoco, city);

portocruzano-porteño (Puerto La Cruz, city).

We should also underscore the triplet example of demonyms used to refer to the residents of the city of Maracaibo, the capital of the state of Zulia:

maracaibero - marabino - maracucho.

\section{Brazil}

According to the results of analysing the morphology of Brazilian "gentílicos", the overwhelming majority of the examples of demonyms from this lusophone country contain the suffix -ense (205 matches, i.e., $74 \%$ of the analysed examples), which is similar to the situation in the neighbouring Argentina, Uruguay, and Ecuador $^{10}$ [21. P. 355].

\footnotetext{
${ }^{10}$ In Portuguese language studies the terms gentilico y adjetivo pátrio are equivalent to the Spanish term gentilicio (eng. "demonym").
} 
The second most productive suffix is -ano found in 38 examples: goiano, baiano, sergipano, alagoano, pernambucano, paraibano, rondoniano, acreano, acriano, aguaiano, altairano, amapolitano, anastaciano, aracajuano, corintiano, cuiabano, curitibano, curvelano, dionisiano, entrerriano, eusebiano, florianopolitano, guaiubano, jeceabano, juiz-de-forano, juiz-forano, iguaçuano, itabirano, ouro-pretano, petropolitano, piracicabano, ribeiro-pretano, soteropolitano, anastaciano, riopretano, paulistano, serrano, tricordiano.

The third place goes to the suffix -ino found in nine examples, whereas the least popular suffixes are -ista (five: américo-campista, geralista, paranista, paulista, santista), -eiro (four: brasileiro, mineiro, campineiro, piauizeiro), -ão (one: baião), -és (one: montanhés), and -ante (one: bandeirante). The zero suffix is found in the alternative demonym maranhão for the state of Maranhão (nonetheless, the form macanhense is more frequent).

Some of the suffixes included as formative components in the demonyms of Brazil are typical only of that country and are not found among the examples of demonyms from the Spanish-speaking realm. They originate from the indigenous languages of the Tupi-Guarani group, e.g., the suffixes -oca (carioca, the word oka is officially translated as 'house'), or -ar/-uar/-ara/-uara, usually possess multitude of variants. In the Tupi language the latter suffixes are treated as endings of nouns denoting action-taking persons (an inhabitant of the Brazilian state of Rio Grande do Norte can be called potiguar, petiguar, pitaguar, pitiguar, pitiguara, potiguara, whereas the respective demonyms of indigenous origin for the inhabitants of the state of Para and the city of Manaus in Amazonia will be paroara, parauara, and manauara). ${ }^{11,12,13}$

\section{SO-CALLED TOPONYMIC NICKNAMES}

We must underline the extraordinary occurrence of the so-called toponymic nicknames (popular or colloquial demonyms in linguistic tradition) often marked by funny, ironic, or xenophobic connotations serving to hyperbolize certain traits of people from the standpoint of the denominator. These colloquialisms are a part of national idiosyncratic terminology, its culturemes [22]. As pointed out by Russian scholar G. Sudar, demonyms and toponymic nicknames have different connotations for they are not used in the same context [23]. Our file and survey data show that, for example, in Argentina a Brazilian can be nicknamed brasuca (not necessarily with pejorative connotation), which may originate from brazo de azúcar or bracero ('semi-slave worker), a Bolivian can be called bolita (meaning "Bolivian

\footnotetext{
${ }^{11}$ potiguar (and the other variants of the name) originates from the Tupi lexeme poti'war meaning "he who loves eating shrimps" and, in addition, refers to the indigenous tribe that used to populate the zone along river río Paraíba do Norte (Buarque de Holanda Ferreira, 1986, p. 1374).

${ }^{12}$ paroara, parauara originate from the Tupi lexeme para'wara [4. P. 39].

${ }^{13}$ manauara originates from the Tupi lexeme manau'wara. Manau stands for the indigenous tribe that used to populate the area along river Rio Negro (Buarque de Holanda Ferreira, 1986, p. 1075).
} 
indigenous by origin"), a Uruguayan can be called yorugua (yo-uru-gua + yoruba $\rightarrow$ "black Uruguayan"), and a Paraguayan — paragua ("peasant with a large sombrero similar in shape to an umbrella (Sp. "paraguas"). In Argentina and Uruguay, e.g., the popular demonym tano is used to refer to descendants of Italian immigrants who arrived mostly in a large migration wave to the Rio de la Plata region from the Kingdom of Naples (here we see napolitano contracted to tano), whereas the nickname "el gallego" is used to denote Argentinians of Spanish origin.

In Colombia people from Guatica are called cebolleros because they devote their time to growing onions (Sp. "cebolla") and to the annually organized onions festival. People of Armenian origin are known as cuyabros; this name is thought to originate from the word for a vessel made from pumpkin or a tropical fruit. In Colombia the word gringo is used to refer to people from the United States, whereas in Brazil this demonym applies to any foreigner. It is a curious fact that Colombians use the toponymic nickname los venecos when they want to refer to people from Venezuela with disdain, though to some people this demonyms seems more neutral than xenophobic. Venecos is a composite word consisting of the morphemes vene (=Venezuelan) and co (=corroncho). In their respect, when Venezuelans feel the need to refer to their neighbours with disdain, they do it using the word los caliches. ${ }^{14}$

We have touched above on the method of giving names to some groups of people according to the indigenous traits they may have or rather the language they use, like in the case of Bolivian movimas. N.M. Firsova points out that Bolivia is divided in three dialectal areas according to the high percentage of mixing between Spanish people and pre-Colombian tribes and the influence of the indigenous languages such as Aymara, Quechua, and Guarani. In zone A stretching across the central and southeastern Andean part (departments of Cochabamba, La Paz, Oruro, Potosí, and Chuquisaca) Bolivians are called collas (sometimes, simply andinos); this toponymic nickname refers to the indigenous people and ancient name of the region - Collasuyo. Zone B (northern and oriental lowlands of the departments of Pando, Beni y Santa Cruz) is populated by cambas called this way due to their linguistic affiliation (Tupi-Guarani group). Chapacos are the Bolivians from the department of Tarija in zone $\mathrm{C}$ characterized by a strong influence of Quechua [24. P. 33-34].

In Colombia the lexeme cachaco is used to refer to the residents of Bogota and serves as the colloquial synonym for the official demonyms bogotano. Another synonym of cachaco is the word rolo that originated as the onomatopoeic name for Creoles who pronounced the sound / $\mathrm{rr} /$ in a distinct manner. ${ }^{15}$ The Dictionary of the

\footnotetext{
${ }^{14}$ Sociedad Geográfica de Colombia, Academia de Ciencias Geográficas (2008). Diccionario de gentilicios de Colombia, IGAC. Bogotá: Imprenta Nacional de Colombia. pp. 158-159. (In Spanish).

${ }^{15}$ Sociedad Geográfica de Colombia, Academia de Ciencias Geográficas (2008). Diccionario de gentilicios de Colombia, IGAC. Bogotá: Imprenta Nacional de Colombia. P. 157. (In Spanish).
} 
Spanish Royal Academy indicates the usage of cachaco in three Latin American countries: Colombia, Puerto Rico y Perú. In Colombia this lexeme means "elegant, helpful, gentlemanly" and "well-educated"; in Peru cachaco refers to "a member of a police corps", and in Puerto Rico it is used to refer to "Spaniards in a good economic position". ${ }^{16}$ It is highly probable that the Colombian uses of cachaco go back to the phonetically transformed noun casaca. ${ }^{17}$ Nonetheless, in Renaud Richard's Dictionary of Latin American Spanish the description of the lexical unit cachaco in Colombia is accompanied by the desp. (despectivo, Sp. for "derogatory") tag and refers to "residents of coastal regions, of the capital or the interior part of the country". 18

In the broadest sense, the noun cachaco refers not only to the residents of the country's capital but, from the standpoint of the coastal population, also to those who populate the entire geographical area of Altiplano Cundiboyacense, earlier populated by the Chibcha tribe. ${ }^{19}$

The phraseological unit used by Luna Cabrera Más contento que cachaco en playa 'More pleased than a cachaco on the beach' refers to the way cachacos are perceived by the people who live along Colombia's Caribbean coastal line and enjoy the advantageous access to the beaches, of which cachacos are geographically deprived [25. P. 137]. We should mention a case when Gabriel Garcia Marquez used the coastal lexeme in his autobiographical works when telling about the times he studied in the city of Zipaquirá in the area populated by cachacos, not far from the capital: Desde aquel día sólo faltó que mis compañeros de clase me proclamaron héroe, y empezaron a llamarme con toda la sorna posible 'el costeño que habló con el rector' (2) 'Since that day I only missed the times when my classmates called me a hero and started to call me with all possible derision " $a$ guy from the seaside" (costeño) who talked to the provost'. ${ }^{20}$

\section{DISCUSSION OF RESULTS}

The analytical study of South American demonyms regarding nine Spanishspeaking countries and Brazil allows us assert that the most frequently used suffixes in the demonyms are -eño, -ense, and -ino (see Table 1).

It is surprising that Brazilians spacify the Portuguese demonyms used to refer to residents of some Spanish-speaking cities and countries and attach to these words suffixes that suit these words in Spanish but appear pronounceable in Portuguese:

\footnotetext{
${ }^{16}$ Asociación de Academias de la Lengua Española, Diccionario de la lengua española, $22^{\text {nd }}$ edition. URL: https://dle.rae.es/cachaco?m=form (accessed: 13.07.2020).

${ }^{17}$ Sociedad Geográfica de Colombia, Academia de Ciencias Geográficas (2008). Diccionario de gentilicios de Colombia, IGAC. Bogotá: Imprenta Nacional de Colombia. P. 157. (In Spanish).

${ }_{18}$ Richard, R. (2006). Diccionario de hispanoamericanismos no recogidos por la Real Academia. Madrid: Cátedra. P. 94.

${ }^{19}$ Comisión de Lingüística de la Academia Colombiana de la Lengua (2009). Breve Diccionario de colombianismos. Bogotá: Academia colombiana de la lengua. P. 39.

${ }^{20}$ García Márquez, G. (2002) Vivir para contarla. Bogotá: Editorial Norma. P. 240.
} 
hondurenho (Honduras) salvadorenho (El Salvador), porto-riquenho (Puerto Rico, though the Castilian diphthong [-ue-] is lost), bogotano (Bogota, Colombia), santiaguino (Santiago, Chile). At first sight, the reason for resorting to the morphological method of borrowing seems odd, but afterwards it becomes understandable because it is easy for Portuguese to adopt original Spanish variants in terms of phonetics and orthography.

Table 1 / Таблица 1

Productivity of suffixes in demonyms of South American countries

Продуктивность суффиксов в демонимах стран Южной Америки

\begin{tabular}{|l|l|l|}
\hline COUNTRY & MOST PRODUCTIVE SUFFIX & EXAMPLE \\
\hline Argentina & -ense & Ushuaia - ushuaiense \\
\hline Uruguay & -ense & Rocha - rochense \\
\hline Paraguay & -eño & Caazapá - caazapeño \\
\hline Chile & -ino & Maipo - maipino \\
\hline Bolivia & -eño & Puna - puneño \\
\hline Perú & -eño & Cuzco - cuzqueño \\
\hline Ecuador & -ense & Bolivar - bolivarense \\
\hline Colombia & -eño & Antioquia - antioqueño \\
\hline Venezuela & -eño & Mérida - merideño \\
\hline Brasil & -ense & Ceará - cearense \\
\hline
\end{tabular}

The various peculiar morphological tendencies detected in the course of analysing the demonyms of South America are exposed below.

1) The reduction of names derived from toponyms of two or more lexical elements, especially in case of anthroponyms: Florencio Varela - varelense (Argentina); Presidente Franco - franqueño (Paraguay); Cardenal Caro cardenalino (Chile); João Pessoa - pessoense (Brasil);

2) Derivation of demonyms originating from hagionyms is a highly spontaneous process, given that the elements $\boldsymbol{S a n / S a n t o}$ of original toponyms are neither always incorporated nor do they follow common determined rules of Spanish, which confirms our hypothesis that the analysed lexical field is a dynamic system;

For example, in Argentina the omission of the agionym component is observed in place names with more than two lexical elements, whereas in the analysed examples from Uruguay no such tendency is noticed. Sometimes, the alveolar sound $[\mathrm{n}]$ changes to the labio-labial sound $[\mathrm{m}]$ in the graphic form of demonyms: San Pedro (Paraguay) - sampedrano.

3) As for the phenomenon of homonymic place names met in South America fairly often, we should emphasize that homonymic demonyms are also derived in the same way: La Paz (Uruguay) / La Paz (Bolivia) — paceño; Salta (Uruguay) / 
Salta (Argentina) - salteño; Trinidad (Uruguay) / Trinidad (Bolivia) - trinitario. In certain cases, however, there is no coincidence of suffixes in respective demonyms, especially when we deal with names derived from religiously marked toponyms: carolino (San Carlos, Uruguay) — sancarleño (San Carlos, Venezuela); asunceno (Asunción, Paraguay) — asuntino (La Asunción, Venezuela);

4) The occasional occurrence of double (twin) or triple (triplet) synonymic demonyms normally brings to light the most often used demonym, its variants, and sometimes the suppletive demonym: Minas Gerais - mineiro/montanhés/ geralista/minense;

5) The suppletive adjective porteño is distinguished by its polysemy in the language realm of South America because it is used not only to refer to the residents of Buenos Aires but also to the population of various Latin American cities with ports: Valparaíso (Chile), Puerto Carreño (Colombia), Puerto Cabello y Puerto La Cruz (Venezuela), Puntarenas (Costa Rica). We can see the reference to the inhabitants of Valparaiso in Chile in the following example:

- En Canadá hay treinta mil chilenos, caso todos de Valparaíso - dijo don Fernando. - Miles hay también en Suecia. Cuesta imaginar a porteños viviendo em el frio y la oscuridad de estos países "There are thirty thousand Chileans in Canada, almost all of them from Valparaiso, — said don Fernando. - There are also thousands in Sweden. It is hard to imagine porteños living in the cold and darkness of such countries" $(3)^{21}$.

\section{Conclusions}

The productivity analysis of suffixes used in forming demonyms is just one of the numerous aspects of the potential study of lexical units belonging to the mentioned field of onomastics. Demonyms represent a kind of linguistic place name codes reflecting national, regional identities and axiological values, especially seen in their alternative variants and toponymical nicknames. Demonyms bear witness rather to linguistic tastes and preferences than to conscious motivation.

To sum up, demonyms and place names are integral parts of the orientation not only in the geographical environment but in the cultural realm as well. Therefore, studying demonyms and toponyms reveals diverse aspects of their statics and dynamics, improves the comprehension of their aesthetic and linguistic manifestations, and makes them effective means of teaching Spanish and Portuguese as foreign languages. The comments on demonyms in courses in Spanish and Portuguese lexicology, translation theory and practice can concern their morphology and semantics, studies of etymology of suppletive demonyms, and their analysis in diverse types of text and discourse.

The usage of demonyms and toponymic nicknames does not confine merely to scientific writings or fiction but is going to play an exponentially more significant

\footnotetext{
${ }^{21}$ Roberto Ampuero, R. (2012). El último tango de Salvador Allende. Buenos Aires: Sudamericana. P. 319.
} 
role in the domain of international relations and intercultural communication, having in mind the complex circumstances in the modern world. Still, lexicologists undoubtedly have a lot of work ahead regarding deepening and systemizing the data offered by this field of semantics.

Future systematization of the demonyms is a rather creative task of modern onomastics, theoretical and applied linguistics that can prove that demonyms rather comprise a category on their own.

\section{References}

1. Moreno de Alba, J.G. (2001). El español en América. México: Fondo de Cultura Económica. (In Spanish).

2. Lipski, J.M. (1996). El español de América. Madrid: Catedra. (In Spanish).

3. Stepanov, G.V. (1979). Linguistic Variability: Case Study of European and Latin American Spanish. Moscow: Nauka. (In Russ.).

4. Reis Melo, C. \& Gomes, J. (2000). Adjetivos pátrios brasileiros. Ao pé da letra, 2, 35-40. (In Portuguese).

5. Morera, M. \& García Padrón, D. (2013). Los sentidos secundarios de las palabras gentilicias. In: Estudios de lingüística: investigaciones, propuestas y aplicaciones. València: Universitat de València. pp. 461-467. (In Spanish).

6. Almela Pérez, R. (2013). Categoría, función y sentido de los gentilicios. Anuario de estudios filológicos, 36, 5-18. (In Spanish).

7. Lang, M.F. (2013). Spanish Word Formation. London-New York: Routledge.

8. Fajardo Chávez, S. \& Kordić Riquelme, R. (2019). Consideraciones morfológicas sobre sobre el gentilicio. Un caso: Chile. RILCE: Revista de Filología Hispánica, 35(2), 416 - 440. (In Spanish).

9. Li, W. (2018). Translanguaging as a Practical Theory of Language. Applied Linguistics, 39(1), 9-30.

10. Chesnokova, O.S., Naydenova, N.S. \& Radović, M. (2020). The Concept of Glory through the Prism of the Illustrious Personalities of the Pacific Alliance and the Perception of Virtual Linguistic Personality. Philological Sciences. Scientific Essays of Higher Education, 3, 67-77. DOI: 10.20339/PhS.3-20.067 (In Russ.).

11. Bakhtin, M. (1986). Aesthetics of Verbal Creation. Moscow: Iskusstvo. (In Russ.).

12. García Mouton, P. (1992). Sobre geografía lingüística del español de América. Revista de Filología Española, 72(3/4), 699-713. (In Spanish).

13. Latorre, G. (1997). Tendencias generales en la toponimia del Norte Grande de Chile. Onomazein, 2, 181-196. (In Spanish).

14. Lehnert Santander, R. (1993). La toponimia quechua de la II Región, Hombre y desierto, 6-7, 89-101. (In Spanish).

15. Lotman,Yu. (1996) Inside Intellectual Realms. Moscow: Yazyki russkoi kulturi, (In Russ.).

16. Chesnokova, O.S. (2011). Toponimia latinoamericana: un enfoque semiótico, Forma y Función, 24(2), 11-24. (In Spanish).

17. Chesnokova, O.S. (2014). Colombia in the Spanish-Speaking World. Moscow: RUDN. (In Russ.).

18. Talavera-Ibarra, P.L. (2016). History of the Term 'Latin America' on the American Continent. Language in a global context Latin America today as a cultural and linguistic phenomenon. In: Collection of reviews and abstracts of Linguistics Department, E.A. Kazak (Ed.) Series. Theory and history of linguistics. Moscow: INION. pp. 11-21.

19. Kordić Riquelme, R. \& Ferreccio Podestá, M. (2014). Topónimos y gentilicios de Chile. Santiago de Chile: RiL. (In Spanish). 
20. Radović, M. (2014). Linguistic Analysis of Demonyms in Argentinian and Chilean Spanish. Sovremennye issledovaniya sotsial'nykh problem, 1(17), 12-29. (In Russ.).

21. Rádovich, M. (2016). Los gentilicios en las variantes nacionales sudamericanas de la lengua española. In: El mundo iberoamericano, las tradiciones y las tendencias contemporáneas. Moscow: IMI MGIMO MID Rossii. pp. 353-359. (In Russ.).

22. Chesnokova, O.S. (2016). Ethnolinguistic Realia of Colombia. In: Yazyk v global'nom kontekste, Latinskaya Amerika segodnya kak kul'turno-yazykovoy fenomen. Moscow: INION. pp. 22-33. (In Russ.).

23. Sudar, G.S. (2010). Toponymic Nickname. In: The Issues of Ibero-Romance Linguistics. Moscow: MGU. pp. 229-235. (In Russ.).

24. Firsova, N.M. (2008). Spanish and the Culture of Bolivia. Moscow: RUDN. (In Russ.).

25. Luna Cabrera, J.E. (2005). Su Majestad el Refrán. Manizales: Editorial Zapata. (In Spanish).

\section{Библиографический список}

1. Moreno de Alba J.G. El español en América. México: Fondo de Cultura Económica, 2001.

2. Lipski J.M. El español de América. Madrid: Catedra, 1996.

3. Степанов Г.В. Лингвистическая изменчивость: пример европейского и латиноамериканского испанского. М.: Наука, 1979.

4. Reis Melo C., Gomes J. Adjetivos pátrios brasileiros // Ao pé da letra. 2000. № 2. P. 35-40.

5. Morera M., García Padrón D. Los sentidos secundarios de las palabras gentilicias // Estudios de lingüística: investigaciones, propuestas y aplicaciones. València, 2013. P. 461-467.

6. Almela Pérez $R$. Categoría, función y sentido de los gentilicios // Anuario de estudios filológicos. 2013. № 36. P. 5-18.

7. Lang M.F. Spanish Word Formation. London-New York: Routledge, 2013.

8. Fajardo Chávez S., Kordić Riquelme R. Consideraciones morfológicas sobre sobre el gentilicio. Un caso: Chile // RILCE: Revista de Filología Hispánica. 2019. № 35(2). P. 416- 440.

9. $L i W$. Translanguaging as a Practical Theory of Language // Applied Linguistics. 2018. № 39(1). P. 9-30.

10. Чеснокова О.С., Найденова Н.С., Радович М. Концепция славы через призму выдающихся личностей Тихоокеанского альянса и восприятие виртуальной языковой личности // Филологические науки. Научные очерки высшего образования. 2020. № 3. С. 67-77. https://doi.org/10.20339/PhS.3-20.067

11. Бахтин М. Эстетика словесного творчества. М.: Искусство, 1986.

12. García Mouton P. Sobre geografía lingüística del español de América // Revista de Filología Española. 1992. № 72(3/4). P. 699-713.

13. Latorre G. Tendencias generales en la toponimia del Norte Grande de Chile // Onomazein. 1997. № 2. P. 181-196.

14. Lehnert Santander R. La toponimia quechua de la II Región // Hombre y desierto. 1993. № 6-7. P. 89-101.

15. Лотман Ю. Внутри интеллектуальных сфер. М.: Языки русской культуры, 1996.

16. Chesnokova O.S. Toponimia latinoamericana: un enfoque semiótico // Forma y Función. 2011. № 24(2). P. 11-24.

17. Чеснокова О.С. Колумбия в испаноязычном мире. М.: РУДН, 2014.

18. Талавера-Ибарра П.Л. История термина «Латинская Америка» на американском континенте. Язык в глобальном контексте. Латинская Америка сегодня как культурно-языковой феномен // Сборник обзоров и рефератов. Центр гуманит. науч.-информ. исслед. Отд. языкознания; Сер. Теория и история языкознания. Отв. ред. Е.А. Казак. М.: ИНИОН PAH, 2016. C. $11-21$.

19. Kordić Riquelme R., Ferreccio Podestá M. Topónimos y gentilicios de Chile. Santiago de Chile: RiL, 2014. 
20. Радович М. Лингвистический анализ демонимов в аргентинском и чилийском испанском // Современные исследования социальных проблем. 2014. № 1(17). С. 12-29.

21. Радович $M$. Los gentilicios en las variantes nacionales sudamericanas de la lengua española // El mundo iberoamericano, las tradiciones y las tendencias contemporáneas. М.: ИМИ МГИМО МИД России, 2016. С. 353-359.

22. Чеснокова О.С. Этнолингвистическая реальность Колумбии. Язык в глобальном контексте, Латинская Америка сегодня как культурно-языковой феномен. М.: ИНИОН, 2016. C. $22-33$.

23. Сударь Г.С. Топонимический псевдоним. Проблемы иберо-романской лингвистики. М.: МГУ, 2010. С. 229-235.

24. Фирсова Н.М. Испанский язык и культура Боливии. М.: РУДН, 2008.

25. Luna Cabrera J.E. Su Majestad el Refrán. Manizales: Editorial Zapata, 2005.

\section{Информация об авторах:}

Чеснокова Ольга Станиславовна, доктор филологических наук, профессор, профессор кафедры иностранных языков филологического факультета РУДН, сфера научных интересов: теория и практика межкультурной коммуникации, переводоведение, семиотика художественного дискурса, вариативность испанского языка, e-mail: tchesnokova-os@rudn.ru

Радович Мария, кандидат филологических наук, ассистент кафедры иностранных языков филологического факультета Российского университета дружбы народов (РУДН); сфера научHblx интересов: топонимика испанского языка, вариативность испанского и португальского языков, лингвокультурология, лексикография, межкультурная коммуникация, переводоведение; e-mail: radovich-m@rudn.ru

Котеняткина Ирина Борисовна, кандидат филологических наук, доцент кафедры иностранных языков филологического факультета РУДН; сфера научных интересов: язык и культура Гватемалы, лексикология, семантика, этимология, социолингвистика, национальные варианты испанского языка; e-mail: kotenyatkina-ib@rudn.ru

\section{Information about the authors:}

Olga S. Chesnokova, Dr, Professor of Foreign Languages Department at RUDN University; research interests: theory and practice of intercultural communication, translation studies, semiotics of literary discourse, Spanish language varieties; e-mail: tchesnokova-os@rudn.ru

Marija Radović, Ph.D., Assistant Lecturer at the Department of Foreign Languages of the Faculty of Philology of the RUDN University. Her research interests include Spanish toponymy, variations of the Spanish and Portuguese languages, cultural linguistics, lexicography, intercultural communication and translation studies; e-mail: radovich-m@rudn.ru

Irina B. Kotenyatkina, PhD, Associate Professor of the Department of Foreign Languages of RUDN University; research interests: the language and culture of Guatemala, lexicology, semantics, etymology, sociolinguistics, national varieties of Spanish; e-mail: kotenyatkina-ib@rudn.ru 